\title{
Health professionals' knowledge of prevention strategies and protocol following percutaneous injury
}

\author{
C Bodkin, M Sc (Nursing), Department of Nursing Education, University of the \\ Witwatersrand \\ J Bruce, PhD (Nursing), Department of Nursing Education, University of the \\ Witwatersrand
}

\section{Abstract}

Prevention strategies and protocols for the management of percutaneous injuries are developed for the purpose of preventing transmission of HIV and other infections. However, implementation thereof requires health professionals to be conversant with the content of protocols and ways to prevent percutaneous injuries. The purpose of the study was to determine health professionals' knowledge of prevention strategies and protocols following percutaneous injury. The purpose was addressed within a quantitative survey design. Data were collected by means of a self-administered questionnaire. The study was conducted at a public-sector tertiary academic hospital in Gauteng. Seven units within the hospital were randomly selected for investigation. These included, trauma, intensive care, medical, surgical, maternity, theatre and paediatrics. A population of 800 health professionals worked within the sampled units. Health professionals were stratified according to the following three categories, doctors, registered and enrolled nurses and medical and nursing students. A sample size of 200 health professionals was purposively selected of which a response rate of $79.5 \%(n=159)$ was achieved. The sample consisted of $76.7 \%(n=122)$ registered and enrolled nurses, $13.2 \%(\mathrm{n}=21)$ doctors and $8.8 \%(n=14)$ medical and nursing students; $1.3 \%(n=2)$ did not specify their health professional category.

Awareness of the existence of a protocol for percutaneous injury amounted to $96.2 \%(n=153)$. General knowledge of the contents of the protocol reflected a different picture; only $26.4 \%(n=42)$ of health professionals could accurately quote the procedure following a percutaneous injury as recommended by the South African Institute of Medical Research (SAIMR) protocol. The lack of knowledge of the existence of a protocol was most evident in the medical and surgical units.

A total of $16.4 \%(n=26)$ of health professionals reported

\section{Abstrak}

Voorkomende strategieë en protokolle vir die hantering van naaldprik-beserings is ontwikkel ten einde die oordrag van HIV en ander infeksies te voorkom. Implementering vereis dat gesondheidspersoneel kennis van die inhoud van die protokolle asook voorkomingstrategieë moet dra. Die doel van hierdie studie was om gesondheidspersoneel se kennis ten opsigte van voorkomingstrategieë en protokolle na naaldprikbesering te bepaal. Die doel is aangespreek deur kwantitiewe opname ontwerp. Data is deur middel van self geadministreerde vraelyse ingesamel. Die studie is in 'n publieke sektor tersiere akademiese hospitaal in Gauteng uitgevoer. Sewe eenhede in die hospitaal is aan die hand van ewekansige steekproef geselekteer. Die geselekteerde eenhede het die trauma, intensiewe sorg, mediese, sjirurgiese, verloskunde, teater and pediatriese eenhede ingesluit. 'n Totale populasie van 800 gesondheidspersoneel is in die geselekteerde eenhede werksaam. Gesondheidspersoneel is volgens drie kategorieeë, naamlik, mediese dokters, geregistreerde en ingeskrewe verpleegkundiges, en mediese en verpleegkunde studente gestratifiseer. 'n Streekproef van 200 gesondheidspersoneel is aan die hand van 'n doelgerigte streekproef geselekteer waarin 'n terugvoersyfer van $79.5 \%(n=159)$ bereik is. Die streekproef samestelling was soos volg: $76.7 \%(n=122)$ geregistreerde en ingeskrewe verpleegkundiges; $13.2 \%$ $(n=21)$ mediese dokters en $8.8 \%(n=14)$ mediese en verpleegkunde studente; $1.3 \%(n=2)$ het nie hul gesondheidspersoneel kategories aangemeld nie.

Die bewusheid van die bestaan van 'n protokol vir naaldprik-beserings was $96.2 \%(n=153)$. Algemene kennis van die inhoud van die protokol het egter ' $n$ ander prentjie gereflekteer; slegs $26.4 \%(n=42)$ van die gesondheidspersoneel kon die prosedure soos deur die SAIMR protokol voorgestel, korrek aanhaal. Die afwesigheid van kennis ten opsigte van die bestaan 
having sustained a percutaneous injury. A doctor $(33.3 \%)$ was more likely to sustain a percutaneous injury than a nurse $(15.6 \%)$. Intensive care units reported the highest incidence of percutaneous injuries $(31 \%$; $\mathrm{n}=9$ ). Health professionals were unlikely to report a percutaneous injury; as only $53.8 \%(n=14)$ reported the injury. The results of this research indicate that although knowledge of protocol and prevention strategies was inadequate these alone are insufficient to reduce the incidence of percutaneous injury.

\section{Introduction}

Reported exposure of health professionals to blood-borne pathogens through accidental percutaneous injury have been widely published (Clark, Sloan \& Aiken, 2002: 1115; Brook \& Bauer, 2002: 71). Prevention strategies and protocols for the management of percutaneous injury and exposure to blood is a high profile topic, with many such protocols being widely distributed within the health care setting. However, by February 2001, 57 health professionals, including 24 registered nurses, in the United States reported to have contracted HIV infection due to percutaneous exposure to HIV infected blood. Despite the implementation of prevention strategies and protocols for the management of percutaneous injury, research findings continue to reveal that some health professionals are not compliant with these strategies and protocols (Gordon, 1999:174). Hence, many health professionals in South Africa are putting themselves at risk of contracting HIV. As a result, it is expected that between 18-35 health professionals worldwide will sero-convert annually due to percutaneous exposure to HIV (Brook \& Bauer, 2002: 71 ).

\section{Background}

A percutaneous injury is an injury resulting in exposure to blood, semen, cerebral spinal fluid, pleural fluid or other serous fluid by means of a needle stick injury, or injury with a contaminated sharp instrument. Specific factors place health professionals at greater risk of sustaining percutaneous injuries. Previous research has identified that percutaneous injuries are most likely to occur during the drawing of blood samples and during suturing (Fokin \& Robiesek, 2000:14; Henderson, 1999:7; Karstaedt \& Pantanowitz, 2001:59). Other reported causes of injury include, a patient that moved unexpectedly, a carelessly placed sharp, accidentally mishandled needles and full hazardous waste containers (Gordon, 1999:174). Although prohibited in hospitais in the United States, recapping of needles was a large contributor towards percutaneous injury (Cutlip, 2000:6). Apart from procedures, other risk factors for sustaining percutaneous injuries include, nurses on units with less than adequate resources, low staffing levels and poor nurse leadership. Within these units nurses were typically twice die protokol was die mees waarneembaarste in die mediese en sjirurgiese eenhede.

Slegs $16.4 \%(n=26)$ van gesondheidspersoneel het 'n naaldprik-besering aangemeld. Ook is die moontlikheid groter dat geneeshere eerder as verpleegkundiges, naaldprik-beserings kon opdoen. Die intensiewesorg eenheid het die hoogste insidensie van beserings gerapporteer $(31 \%, n=9)$. Gesondheidpersoneel neig dartoe om nie die besering aan te meld nie aangesien slegs $53.8 \%(n=14)$ die besering aangemeld het. Die resultate van hierdie studie dui aan dat alhoewel kennis rakende die protokol en voorkomingstrategiee onvoldoende is, hierdie faktore op hul eie egter onvoldoende is on die insidensie van naaldprikbeserings te verlaag.

as likely to report the presence of risks due to staff carelessness, inexperience and inadequate knowledge or supplies (Clark, Sloan \& Aiken, 2002: 1115). Thus personal and work related factors do influence the risk of percutaneous injury.

Other personal and work related factors include health professional category and time of day. Researchers agree that nurses are the most at risk of sustaining a percutaneous injury (Cutlip, 2000:5), with reported incidences ranging from 4.3\% (Clark et al., 2002:1115) to 65\% (Henderson, 1999:23). The reported incidence of percutaneous injures for doctors was 15\% (Fokin \& Robiesek, 2000:14). The time of day also appears to influence the incidence of percutaneous injury. In a study carried out in the United States, $61 \%$ of percutaneous injuries occurred during the day (Gordon, 1999:174) whilst Henderson (1999:23) concluded that $63 \%$ of percutaneous injuries occurred in the afternoon.

Risk factors may be minimised through the implementation of prevention strategies and the introduction of a protocol for the management of percutaneous injuries. Prevention strategies and a management protocol are issued by the South African Institute for Medical Research (SAIMR) now called the Now National Health Laboratory. Health professionals are required to know the content of the protocol. The protocol can be divided into three steps: these include washing of the site of injury, reporting the percutaneous injury and finally steps taken to prevent the transmission of pathogens.

Immediate washing of the injury site is the first step recommended in the protocol. The rationale for this is that research findings support the hypothesis that most of the blood inoculum following percutaneous injury stays at the site of introduction for a substantial period of time, with a gradual release into the vasculature and lymphatics (Fokin \& Robiesek, 2000:14). The second step involves immediate reporting of the percutaneous injury and exposure to blood. Reporting of a percutaneous exposure to blood is important for the following reasons: employers are compelled by law to keep a record of percutaneous injuries and exposures to HIV positive blood. Reporting also affords the health professional the opportunity to have the risk of con- 
tracting HIV assessed and to receive post-exposure prophylaxis (Brook \& Bauer, 2002: 71). Regardless of the benefits, fewer than half $(43 \%)$ of health professionals in the United States report percutaneous injuries to authorities (Henderson, 1999:7). Health professionals give the following reasons for not reporting a percutaneous injury: they fear loss of employment; denial may keep health professionals from reporting these incidents and health professionals are concerned about being ostracised by employers or supervisors through punitive means (Gordon, 1999:174). The third step of the protocol is receiving postexposure prophylaxis in order to prevent transmission of pathogens. The three pathogens believed to pose the most common and significant risk to health professionals exposed through a percutaneous injury are hepatitis B virus (HBV), hepatitis C virus (HCV), and human immunodeficiency virus (HIV) (Cutlip, 2000:5). HIV is of particular concern in South Africa as it is estimated that $24.5 \%$ of pregnant women in South Africa are HIV positive.

Prior to commencing post exposure prophylaxis the health professional's risk of contracting one of the pathogens must be assessed. This involves testing the source patient and the health professional for HBV and HIV. The nature of the injury also affects the risk. It is generally shown that HIV seroconversion is more likely to occur in the following instances, percutaneous injury with a large-diameter needle, deep injury, visible blood on the device, injury sustained during an emergency procedure and the stage of the disease in the source patient (Fokin \& Robiesek, 2000:14; Cutlip, 2000:5).

The rate of seroconversion after percutaneous exposure to HIV infected blood is $0.3 \%$ (Fokin \& Robiesek, 2000:14). However, should the health professional receive immediate post exposure prophylaxis following the percutaneous injury the chance of developing HIV infection could be reduced by $79 \%$. The best results are obtained if post exposure prophylaxis is commenced within one to two hours following exposure and continued for four weeks (Church, 1997:309; Whitfeld, 2000: 33). The drug of choice for post exposure prophylaxis following percutaneous exposure to HIV infected blood is Zidovudine (ZDV or AZT). Additional antiviral agents such as Lamivudine (3TC) and/or Indinavir should be considered depending on the degree of risk of exposure.

Effective prevention strategies and prompt and correct action following a percutaneous injury are necessary to prevent the transmission of HIV and other infections to health professionals. These include preventing personal and work related percutaneous injury risk factors and management following a percutaneous injury including: washing of the site, reporting the percutaneous injury and finally, steps taken to prevent transmission of pathogens.

\section{Problem statement}

In order for a standard protocol for the management of percutaneous injury to be effective health professionals require knowledge of the existence and content of such a protocol. In a study conducted in the United States, $50 \%$ of registered nurses were unaware of a protocol for the management of percutaneous injury (Gordon, 1999:175). Health professionals also require knowledge of strategies for the prevention of percutaneous exposure to blood. Health professionals who have limited knowledge of prevention strategies and protocol for the management of percutaneous injury are placing themselves at risk of contracting HIV or other infections.

\section{Purpose}

The purpose of the study was to determine health professionals' knowledge of prevention strategies and protocol following percutaneous injury, with the intention of making recommendations for the prevention and management of percutaneous injury.

\section{Objectives}

The purpose of the study was addressed through the following objectives:

- Assess the knowledge health professionals have about protocol following percutaneous injury;

- Describe the incidence of percutaneous injury among health professionals over a one year period in relation to health professional category, time ofday and unit allocation and application of knowledge of the protocol following a percutaneous injury;

- Identify and describe the practices of health professionals that resulted in their percutaneous injury;

- Determine the application of strategies to preventpercutaneous injury.

\section{Research methodology Research design}

The purpose of the research was addressed within a survey design and through the use of descriptive methods. Data were collected by means of a self-administered questionnaire. Data collection was designed in accordance with quantitative methods. Data were analysed by means of descriptive statistics.

\section{Research setting}

The study was conducted at a public-sector tertiary academic hospital in Gauteng. The SAIMR has formulated, distributed and implemented a standard protocol for the management of percutaneous injuries within this hospital .

\section{Population and Sampling}

Seven units within the hospital were randomly selected for investigation. These included trauma, intensive care, medical, surgical, maternity, theatre and paediatrics. A population of 800 health professionals worked within the sampled units. Health professionals were stratified according to the following three categories: doctors, registered and enrolled 
nurses, medical and nursing students. As the number of health professionals within in each unit differed, $25 \%$ of the staff for each unit was purposively sampled amounting to a sample size of two hundred $(n=200)$. Criteria for inclusion were health professional's age (18 to 65 years of age) and full time eniployee or student status. Agency and parttime staff were excluded.

A response rate of $79.5 \%(n=159)$ of the purposively selected sample was achieved. The sample consisted of 76.7 $\%(\mathrm{n}=122)$ registered and enrolled nurses, $13.2 \%(\mathrm{n}=21)$ doctors and $8.8 \%(n=14)$ medical and nursing students; $1.3 \%(n=2)$ did not specify their health professional category.

\section{Data Collection}

This study replicated two studies conducted in the United States by independent researchers. The Centre of Disease Control (1995) conducted the first study and Aiken, Sloan and Klocinski (1997) conducted the second study. The questionnaire items were derived from these two studies, and from the standard protocol developed by the SAIMR.

Data were collected by means of a self-administered questionnaire, which was distributed at the beginning of each shift and collected at the end of the same shift. The following questions were addressed: awareness about the existence of a protocol, awareness of the content of the protocol, channels health professionals should use to report percutaneous injury, time period in which percutaneous injury should be reported and when post-exposure prophylaxis should be commenced. The incidence of percutaneous injury was observed, type of injury sustained, time of day that the injury was sustained and health professional category. Action taken following percutaneous injury involved questioning the method of reporting the exposure and whether post-exposure prophylaxis was implemented taken. Finally, health professionals were required to describe the action that lead to the percutaneous injury and the steps they would take in order to prevent a percutaneous injury.

\section{Results and discussion \\ Knowledge of the SAIMR protocol}

The knowledge health professionals have about protocol following percutaneous exposure to blood, includes awareness of existence of a protocol and knowledge of the content of the SAIMR protocol. Almost all participants $(96.2 \%, n=153)$ were aware of the existence of a protocol for percutaneous injury. Knowledge of the content of the protocol reflected a different picture; only $26.4 \%(n=42)$ of health professionals could accurately explain the procedure following a percutaneous injury as recommended within the standard SAIMR protocol. In order to be described as having knowledge about protocol a health professional was required to give all of the following information: wash the wound under running water, report the incident immediately to the charge person or casualty, have blood taken from oneself and from the patient for HIV, syphilis and hepatitis B and

finally, access the need for post-exposure prophylaxis, which must be commenced immediately if deemed necessary.

Most health professionals would only wash the injury under running water. Health professionals lacked knowledge of the correct method and route of reporting a percutaneous injury and in taking of blood samples following percutaneous injury. The correct channels of reporting and method of reporting percutaneous injury was explained by $30 \%(n=48)$ of the respondents. Immediate reporting of an injury was indicated by $70 \%(\mathrm{n}=111)$ of health professionals. A further $18.9 \%(n=30)$ of health professionals felt that it is only necessary to report the injury and commence post exposure prophylaxis more than one day after the injury. The remaining $4.4 \%(n=7)$ of health professionals would not consider reporting a percutaneous injury at all.

Lack of knowledge of the existence of a protocol was most evident in the medical and surgical units. In these units $61 \%$ and $67 \%$ of health professionals respectively were aware of the existence of a protocol. All (100\%) health professionals within the trauma unit, labour ward and theatre had knowledge of the existence of the SAIMR protocol. Health professionals in the medical (14.6\%) and surgical $(12.5 \%)$ wards were least likely to correctly state the procedure to be followed, after percutaneous exposure to blood. Health professionals in the labour ward (31.6\%) and ICU $(31 \%)$ were most likely to correctly state the procedure to be followed after a percutaneous injury (see Table 1).

\section{Table 1: Awareness and content knowledge of the SAIMR protocol}

\begin{tabular}{|l|l|l|}
\hline Unit & $\begin{array}{l}\text { Awareness of } \\
\text { existence of a } \\
\text { protocol } \\
(\%)\end{array}$ & $\begin{array}{l}\text { Knowledge of } \\
\text { contents of protocol } \\
\text { for percutaneous } \\
\text { exposure to blood (\%) }\end{array}$ \\
\hline $\begin{array}{l}\text { Trauma } \\
(n=11)\end{array}$ & 100 & 27.3 \\
\hline $\begin{array}{l}\text { ICU } \\
(n=29)\end{array}$ & 96 & 31 \\
\hline $\begin{array}{l}\text { Medical } \\
(n=41)\end{array}$ & 61 & 14.6 \\
\hline $\begin{array}{l}\text { Surgical } \\
(n=47)\end{array}$ & 67 & 31.6 \\
\hline $\begin{array}{l}\text { Labour } \\
(n=19)\end{array}$ & 100 & 17.2 \\
\hline $\begin{array}{l}\text { Theatre } \\
(n=29)\end{array}$ & 100 & 30.4 \\
\hline $\begin{array}{l}\text { Paediatrics } \\
(n=23)\end{array}$ & 93 & \\
\hline
\end{tabular}




\section{Incidence of percutaneous exposure to blood}

The incidence of percutaneous exposure to blood among health professionals is described in relation to health professional category, time of day and unit allocation. A total of $16.4 \%(n=26)$ of health professionals reported having sustained a percutaneous injury in a one year period. The SAIMR (1999) reports an incidence of $8.2 \%$ of percutaneous injuries among staff over a one-year period at an academic hospital. The result obtained in this study was twice as high as that reported by the SAIMR Of the 26 individuals sustaining percutaneous injuries $73.1 \%(n=19)$ were nurses and $26.9 \%(n=7)$ were doctors. None of the students reported having sustained a percutaneous injury. However, only $15.6 \%(n=19)$ of nurses sustained injuries as opposed to $33.3 \%(n=7)$ of doctors.

The incidence of percutaneous injury reported among nurses $(15.6 \%)$ is lower than expected with reference to previous studies. However, the incidence of percutaneous injuries reported among doctors (33.3\%) within this study is higher than the $15 \%$ reported in previous research (Fokin \& Robiesek, 2000:14).

There was no difference in the incidence of injuries sustained at night and during the day; $50 \%(n=13)$ of injuries were sustained during the day. It can be concluded from this result that health professionals working within this public sector tertiary institution are equally exposed to the risk factors associated with sustaining a percutaneous injury during day and night timework.

Intensive care unit staff reported the highest incidence of percutaneous injuries; $31 \%(n=9)$ of ICU staff reported sustaining a percutaneous injury. The percutaneous injuries sustained in ICU's constituted $34.6 \%$ of the total injuries sustained within the hospital. Other at risk areas were the trauma unit where $18.2 \%$ of staff reported percutaneous injuries and theatre where $17.2 \%(n=29)$ of staff reported percutaneous injuries. Health professionals working in surgical and medical units were least likely to sustain a percutaneous injury; $7.5 \%(n=41)$ of health professionals in the medical unit and $4.2 \%(n=47)$ of health professionals in the surgical unit reported a percutaneous injury (see Table 2 ).

\section{Actions taken following percutaneous exposure}

Actions taken following percutaneous injury among health professionals are described in relation to reporting of the injury and whether post exposure prophylaxis was taken. Of the 26 health professionals sustaining percutaneous injuries over a one-year period, $53.8 \%(n=14)$ reported the injury. Health professionals in this study stated that they did not report the percutaneous injury for the following reasons: the risk of contracting HIV was negligible, did not know that they should report the percutaneous injury, did not know the route of reporting the percutaneous injury and reported the stigma attached to sustaining a percutaneous injury.

Post-exposure prophylaxis was taken by $50 \%(n=13)$ of health professionals who sustained a percutaneous injury. Health professionals who did not take post-exposure prophylaxis posited the following reasons:

- In the hospital in which the study was conducted, health professionals are required to report the percutaneous injury at a different department to which the injury is sustained, and this serves as an inconvenience;

- Health professionals felt that there was no risk of them contracting HIV or any other infection from the injury, so it was unnecessary to take post-exposure prophylaxis.

- Health professionals were reluctant to take post exposure prophylaxis due to the side effects. Of the health professionals who had received post-exposure prophylaxis, $74 \%$ reported side effects. The most common side effect reported in literature was nausea (Bartlett \& Gallant, 2000: 70).

- Health professionals reported reluctance to take post-exposure prophylaxis due to the long 
duration of the treatment regime. Bartlett and Gallant (2000:70) reported that if health professionals do choose to take post exposure prophylaxis they stop the medication before completing the four-week programme.

\section{Table 3: Means of sustaining the percutaneous injury}

\begin{tabular}{|l|l|l|}
\hline Health professional activity & $\mathbf{n = 2 6}$ & Percentage \\
\hline Taking of a blood sample & 4 & $15.40 \%$ \\
\hline Incorrect disposal of sharps & 3 & $11.50 \%$ \\
\hline Administering a subcutaneous injection & 1 & $3.80 \%$ \\
\hline Taking blood from a violent patient & 1 & $3.80 \%$ \\
\hline Receiving instruments in theatre & 2 & $7.70 \%$ \\
\hline Recapping of a needle & 1 & $3.80 \%$ \\
\hline Suturing & 2 & $7.70 \%$ \\
\hline Did not specify & 12 & $46 \%$ \\
\hline
\end{tabular}

\section{Means of sustaining the percutaneous injury}

Most injuries were acquired whilst taking a blood sample $(15.40 \%)$ and due to incorrect disposal of sharps (11.5\%). Refer to Table 3 for the means by which percutaneous injuries were sustained.

\section{Prevention strategies}

Health professionals were requested to recommend strategies for the prevention of percutaneous injuries. The following recommendations were made:

- Wear gloves, a protective gown and a mask;

- Avoid recapping of needles following invasive procedures;

- Ensure that the sharp is correctly disposed of within a sharps container and ensure that the sharps container is not overfilled;

- Health professionals should avoid working long hours;

- All patients should be regarded as HIV positive and treated with universal precautions;

- Theatre staff should not accept a suture needle in their hand;

- Use the required instruments when suturing. Avoid using ones fingers to receive the needle whilst suturing, rather use forceps and a needle holder;

- Concentrate and pay attention;

- Ongoing education and reinforcement of universal precautions and on the prevention of percutaneous injuries

The prevention strategies recommended by the health professionals can be elaborated upon using the findings of the study to formulate recommendations for the prevention and management of percutaneous injuries and thus the prevention of occupationally acquired HIV and other infections.

\section{Recommendations}

Recommendations for the prevention of occupationally acquired HIV should contain the following components; firstly, the standard protocol for the management of a percutaneous injury should be distributed to all health professionals. This protocol should also include the prevention of hepatitis B and $\mathrm{C}$ through percutaneous injury. Secondly, distribution of antiretrovirals for post exposure prophylaxis should be available 24 hours a day as 'starter packs'. A starter pack includes 7 days worth of - AZT, 3TC, and indinavir. Thirdly, a format of reporting percutaneous injuries should be devised and reporting should be mandatory. Fourthly, ongoing follow-up of the HIV exposed health professional is required. This will assist in identifying adverse reactions to antiretroviral therapy and seroconversion rates among HIV exposed health professionals. Finally, improvement of laboratory testing and rapid acquisition of HIV serology testing is necessary. Such laboratory services should be available 24 hours a day.

Percutaneous exposure to HIV infected blood may be reduced by staff education, implementation of prevention strategies and the use of a standard protocol for the management of a percutaneous injury. In addition managers of health institutions and policy makers must also address the effect of staffing levels and work environments on these percutaneous injuries.

\section{Conclusions}

In conclusion, health professionals in this study were aware of a protocol for the management of percutaneous injury. However, the general knowledge of the content of the protocol was poor. The lack of knowledge of the existence and content of a protocol for the management of a percutaneous injury was most evident in the medical and surgical units. A total of $16.4 \%$ of health professionals reported having sustained a percutaneous injury, with doctors being more likely to sustain a percutaneous injury than nurses. Intensive care unit staff reported the highest incidence of percutaneous injuries. Health professionals were unlikely to report a percutaneous injury and were reluctant to take post exposure prophylaxis.

The results of this research indicate that protocol and prevention strategies alone are insufficient to reduce the incidence of percutaneous injury. Remedying problems of understaffing, inadequate administrative support, poor morale in hospitals and beliefs around percutaneous injury are among the most important steps in building a safer working environment. 


\section{Acknowledgements}

The authors would like to acknowledge the participation of Rehana Loonat, Vusi Ndaba, Kogielambal Padayachee and Gertrude Ramasodi during data collection.

\section{References}

AIKEN, LH; SLOAN, DM \& KLOCINSKI, JL 1997: Hospital nurses occupational exposure to blood: Prospective, retrospective and institutional reports. American Journal of Public Health. 87(1):103-107

BARTLETT,JG \& GALLANT, JE 2000: 2000-2001 Medical management of HIV infection. Baltimore: John's Hopkins University.

BROOK, PS \& BAUER, J 2002: The legal realities of HIV exposure. Registered Nurse. 64(12):71-74.

CENTRE FOR DISEASE CONTROL 1995. Case control study of HIV seroconversion in health care workers after percutaneous exposure to HIV infected blood in France, United States and United Kingdom. Centre for Disease Control .44(50)

CHURCH, JA 1997: Human Immunodeficiency Virus. Paediatrics, 100(20):309-311.

CLARK, SP; SLOAN, DM \& AIKEN, LH 2002: Effects of hospital staffing and organisational climate on needlestick injuries to nurses. American Journal of Public Health. 92(7):1115-1120.

CUTLIP, K 2000: Preventing needlestick injuries in the health care setting. Hospital Topics. 78(1):5-9.

GORDON, GP 1999: Practice behaviours of RNs related to hazardous risks within the clinical setting. MEDSURG Nursing, 8(3): 174-177.

HENDERSON, CW 1999: Only 43\% of medical students report sharps injuries. Blood Weekly. 12(13):7-9.

FOKIN, AA \& ROBIESEK, F 2000: Accidental injuries by HIV contaminated instruments in the health provider or research environments: can seroconversion be prevented. American Surgeon. 66(1):14-21.

KARSTAEDT, AS \& PANTANOWITZ, L 2001: Occupational exposure of interns to blood in an area of high HIV seroprevalence. South African Medical Journal.99( 1 ):5760 .

WITFELD, M 2000: Treating needlestick injuries reduces infection risk. Australian Nursing Journal. 8(1):33-35. 